\title{
Internationalisation of the Malaysian Higher Education System Through the Prism of South-South Cooperation
}

\author{
Chang-Da Wan and Morshidi Sirat
}

\begin{abstract}
Many of the internationalisation efforts in Malaysia have focused on enhancing collaboration with developed economies and Western systems. This article seeks to fill a gap in the literature by examining six initiatives to internationalise higher education within the Malaysian higher education system through the prism of South-South cooperation. It showcases the ways in which Malaysia participated in such initiatives and illustrates four levels of engagement ranging from government-to-government, institution-to-institution, international organisation-to-government using universities as intermediaries, and regional networks with Malaysian universities playing a significant role.
\end{abstract}

Key Words: Malaysia, South-South cooperation, Global South, internationalisation of higher education, higher education policy

Un grand nombre d'efforts d'internationalisation de l'enseignement supérieur en Malaisie s'est concentré sur le développement de collaborations avec les économies développées et les systèmes occidentaux. Cet article cherche à combler une lacune de la littérature en examinant six initiatives visant à internationaliser l'enseignement supérieur au sein du système malaisien grâce à des coopérations sud-sud. Il expose l'engagement de la Malaisie dans de telles initiatives et illustre quatre niveaux d'engagement : intergouvernemental, interinstitutionnel, entre une organisation gouvernementale

ABOUt THE AUtHORS: CHANG-DA WAN is a Senior Lecturer at National Higher Education Research Institute (IPPTN), Universiti Sains Malaysia, Malaysia. E-mail: changda.wan@ usm.my

MORSHIDI SIRAT is Professor and Senior Research Fellow, National Higher Education Research Institute (IPPTN), Universiti Sains Malaysia, Penang, Malaysia. E-mail: morshidi20I2@gmail.com 
et un gouvernement en utilisant des universités comme intermédiaires et au sein des réseaux régionaux en donnant un rôle essentiel aux universités malaisiennes.

\section{Introduction}

Malaysia is a developing country that is striving to become a developed one. It recognises that one of the keys in achieving this ambitious goal is to focus on the development of its higher education (HE) system. The National Higher Education Strategic Plan 2007-2020 (NHESP) was formulated in 2007 to unleash HE's potential to transform the country by bolstering competition and enhancing national productivity and innovation (MOHE, 2007). In the era of globalisation, national HE cannot exist in vacuum; hence, the internationalisation of Malaysian HE is a key strategic thrust of the NHESP. It aimed to establish Malaysia as an international hub of higher educational excellence (MOHE, 2007, p.I2).Moreover, the Malaysia Education Blueprint (Higher Education) 2015-2025 that followed the NHESP, identified global prominence through internationalisation as one of the ten shifts required to enhance the Malaysian HE system (MOE, 20I5a).

As a developing country, Malaysia's internationalisation of HE has not been confined to enhancing networks and interaction with developed countries. A significant proportion of regional and global interactions across the HE system, institutions and individuals, have taken place with fellow developing and least developing countries. The perception that Malaysian universities always look to Harvard, Oxbridge and other top-ranked global universities in order to enhance their own image is not always true. During the NHESP period, equal emphasis was placed on collaboration with universities of the same standing. More importantly, Malaysian universities were mandated to collaborate with universities in the ASEAN region in order to promote an ASEAN collaborative and cooperative spirit. Thus, this article explores the ways and extent to which internationalisation of the Malaysian HE system progresses through South-South cooperation and interaction. The first part examines the concept of South-South cooperation by drawing on the literature on knowledge development, developmental studies, globalisation and colonisation. Having established the conceptual lens, the second part of the article explores South-South initiatives and programmes undertaken in Malaysia to enhance internationalisation.

\section{South-South Cooperation}

In developmental discourse, developed countries are termed as the North, and developing and least developed countries as the South. The term South or more accurately, the Southern Theory, also implies the idea of decoloni- 
sation (Connell, 20I4). Conceptually, theories that use these concepts carry with them historical and geopolitical contexts, as well as social thought and hegemony.

Some scholars argue that there is much to learn from crossing different contexts, especially from north to south, where for instance, researchers from the north can learn the 'multiple realities' when crossing the boundary to study the south (Maxwell, I998). On the other hand, others argue that there is a need to discard the hegemonic influence of the north in understanding other contexts. For example, Alatas (2006) outlined the distinctive social-scientific thought in the Middle East and Asia, which differs from the models in northern societies. Similarly, Chakrabarty (2000) reasoned that European social history could not be translated into the context of India. Connell (20I4) postulates that, not switching contexts, but instead focusing on the use of southern theory and perspective could develop new knowledge and learning about the subject.

The concept of South-South mainly emerged to describe a cooperative form of development on the African continent with other developing countries. Importantly, this form of cooperation also relates to the concept of symmetric relations or soft powers, which are considered the opposite of the imperialist or coercive values of colonisation. However, Amanor (20I3) contends that even such forms of cooperation have been influenced, albeit indirectly, from the north. The role of the United States in the late I940s and I950s in creating new paradigms of the colonial framework and subsequently the Cold War shows that, competing geopolitical interests exist in many cooperative forms of development.

With the emergence of South-South cooperation, the United Nations (UN) established an office to oversee this form of development and collaboration. The United Nations Office for South-South Cooperation (UNOSSC) has outlined guiding principles, which include respect for national sovereignty, national ownership and independence, equality, nonconditionality, non-interference in domestic affairs and mutual benefit. However, the most basic principle is that this form of cooperation must be determined by developing countries and manifest solidarity among the peoples and countries of the south in contributing to their national well-being, collective self-reliance and attainment of developmental goals (UNOSSC, n.d.).

\section{Malaysia and its South-South Partners}

Malaysia's aspiration to become an international hub of higher educational excellence required an understanding of the competitive HE landscape. Guided by the blue ocean strategy, Malaysia adopted a strategy of global engagement, particularly with countries which are currently developing 
their HE systems (MOHE, 2OII). In other words, such engagement will be in the form of South-South cooperation and interaction.

Furthermore, since developing countries are heterogeneous with their own characteristics and idiosyncrasies, internationalisation would require segmentation of markets to identify preferred partner countries. This was based on socio-economic demographics and estimated demand for HE (see Table I).

Table 1. Segmentation of Markets

\begin{tabular}{|c|c|c|c|c|}
\hline & \multicolumn{3}{|c|}{$\begin{array}{l}\text { Demand for Higher Education (Higher Education Enrolment/ } \\
\text { Average Population) }\end{array}$} \\
\hline & & High & Moderate & Low \\
\hline \multirow{3}{*}{ 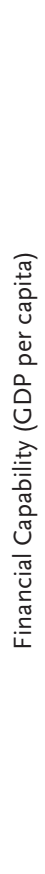 } & $\begin{array}{l}\text { High (More than } \\
\text { USD6,ooo per } \\
\text { capita) }\end{array}$ & $\begin{array}{l}\text { Bahrain, Brunei, } \\
\text { Kuwait, Libya, Oman, } \\
\text { Qatar, Saudi Arabia, } \\
\text { United Arab Emirates }\end{array}$ & & Equatorial Guinea \\
\hline & $\begin{array}{l}\text { Moderate } \\
\text { (Between } \\
\text { USD1,100 and } \\
\text { USD6,00o per } \\
\text { capita) }\end{array}$ & $\begin{array}{l}\text { Algeria, China, Egypt, } \\
\text { Iran, Iraq, Jordan, } \\
\text { Lebanon, Mauritius, } \\
\text { Morocco, South } \\
\text { Africa, Thailand, } \\
\text { Tunisia }\end{array}$ & $\begin{array}{l}\text { Botswana, } \\
\text { Cape Verde, } \\
\text { Gabon, } \\
\text { Namibia, } \\
\text { Swaziland }\end{array}$ & Angola, Maldives \\
\hline & $\begin{array}{l}\text { Low (Less than } \\
\text { USD } 1,100 \text { per } \\
\text { capita) }\end{array}$ & $\begin{array}{l}\text { Indonesia, Liberia, } \\
\text { Mongolia, Myanmar, } \\
\text { Philippines, Vietnam }\end{array}$ & $\begin{array}{l}\text { Bangladesh, } \\
\text { Cambodia, } \\
\text { India, Ivory } \\
\text { Coast, Nepal, } \\
\text { Nigeria, } \\
\text { Pakistan, } \\
\text { Sudan, Yemen }\end{array}$ & $\begin{array}{l}\text { Benin, Burkina, Burundi, } \\
\text { Cameroon, Republic of } \\
\text { Central Africa, Chad, } \\
\text { Comoros, Congo, } \\
\text { Djibouti, Eritrea, Ethiopia, } \\
\text { Gambia, Ghana, Guinea, } \\
\text { Guinea-Bissau, Kenya, } \\
\text { Lesotho, Madagascar, } \\
\text { Malawi, Mali, Mauritania, } \\
\text { Mozambique, Niger, } \\
\text { Papua New Guinea, } \\
\text { Rwanda, Senegal, } \\
\text { Sierra Leone, Tanzania, } \\
\text { Togo, Uganda, Zambia, } \\
\text { Zimbabwe }\end{array}$ \\
\hline
\end{tabular}

Adapted from: MOHE, 2011

The list of developing countries was predominantly Islamic, neighbouring countries in Southeast Asia (ASEAN) as well as those from the Middle East and the African continent. However, it is important to point out that segmentation of markets aimed to identify countries whose students could 
be attracted to pursue HE in Malaysia. The form of South-South interaction was predominantly one-way from these developing countries to Malaysia, as illustrated by the number of international students enrolled in the country's higher education institutions (HEIs). Conversely, a large number of Malaysian students studying abroad were pursuing their studies in developed countries such as the United Kingdom and Australia; these two countries hosted 36 percent of the total number of students abroad (MOE, 2OI4).

\section{South-South Programmes}

A number of South-South programmes are carried out in Malaysia to enhance internationalisation in HE. They can be categorised into instances where Malaysia is directly involved and indirectly involved, but contributing in a larger group. These programmes can also be classified across four levels of engagement: government-to-government, institution-toinstitution, international organisation-to-government using universities as intermediaries, and regional networks with Malaysian universities playing a significant role.

\section{Malaysia's Global Reach}

Malaysia's Global Reach (MGR) programme is a strategy and action plan for the implementation of the internationalisation thrust in the NHESP. Rather than aiming to recruit international students, it seeks to leverage $\mathrm{HE}$ as a soft power platform to accelerate global engagement. In this instance, the concept of soft power refers to "the capabilities and intentions of Malaysian HEIs to capture the hearts and minds of local and international stakeholders to collectively accept values, ideologies and cultures of learning that can benefit communities" (MOHE, 20II, p. I8). The framework of soft power comprises four principles: appropriateness, affordability, accessibility and availability.

The programme is divided into four main strategies and each has a related cluster of academics, researchers and practitioners (see MOHE, 20II). The first is to strengthen global engagement through knowledge sharing, and the cluster is termed MyExpert. The second strategy is to create a knowledge and skills hub through internationalisation, supported by the MySkill cluster. The third strategy is to leverage on student alumni relations towards internationalisation with its cluster MyAlumni. Finally, the fourth strategy is to enhance the presence of Malaysian HE education through contributions and reputation. Three clusters, namely MyFellow and MyOdyssey for the purpose of familiarisation and MyCommunity for outreach, support the fourth strategy.

A range of activities was carried out under MGR with I5 developing coun- 
tries. The common activities were HE dialogues to mutually understand the development, issues and challenges in HE. Malaysian alumni chapters were also established in many countries including China, Cambodia, Thailand, Laos, Vietnam, Myanmar and Indonesia. In addition to engagement with academia and alumni, MGR also undertakes a series of activities to engage with youth and young leaders in developing countries. These include the Aceh-Malaysia Youth Leadership Conference, the Student Leadership Convention for Malaysia and Indonesia and the Malaysia-Southern Thailand Young Leaders Dialogue.

MGR has also carried out many impactful projects through the South-South cooperation model. They include setting up the Institute of Diplomacy for East Timor, where Malaysian experts developed the training content and conducted a series of training workshops. Information and communications technology (ICT) literacy and science for youth projects were also carried out in East Timor by Malaysian academics with local partners through the MyCommunity cluster. A number of engagement projects to promote community health programmes were introduced in Fiji and Papua New Guinea. Through MGR, Malaysia also shared its experience and collaborated with fellow developing countries to develop a training programme in technical and vocational education and training (TVET), and English language and skills courses in eco-tourism and the Malay language. To further enhance understanding and collaboration with African countries, MGR organised the Malaysia-African Summit in 2014 and is currently exploring the possibility of establishing a Malaysia-Africa Institute in Malaysia to tap into the future growth and expansion of Malaysia with this continent (MOE, 2OI5b).

\section{The CLMV International Development Cooperation in Higher Education}

Malaysia's CLMV International Development Cooperation in Higher Education, known as CLMV, is a research- and project-based engagement programme funded by the Malaysian Ministry of Higher Education (MOHE) with the aim of capacity building and fostering collaboration opportunities. The programme transpired from policy research analysis carried out by the National Higher Education Research Institute from the late I990s. Through the ASEAN University Network in 2005, Malaysia was chosen to spearhead an initiative to play an active collaboration role with CLMV countries (Cambodia, Laos, Myanmar and Vietnam). A series of workshops and dialogues took place in 2008 and 2009 in Malaysia as well as the CLMV countries to formalise a framework for the Malaysia-CLMV collaboration; this is illustrated in Figure I. 
Figure 1. Objectives and expected outcomes of the Malaysia-CLMV collaboration

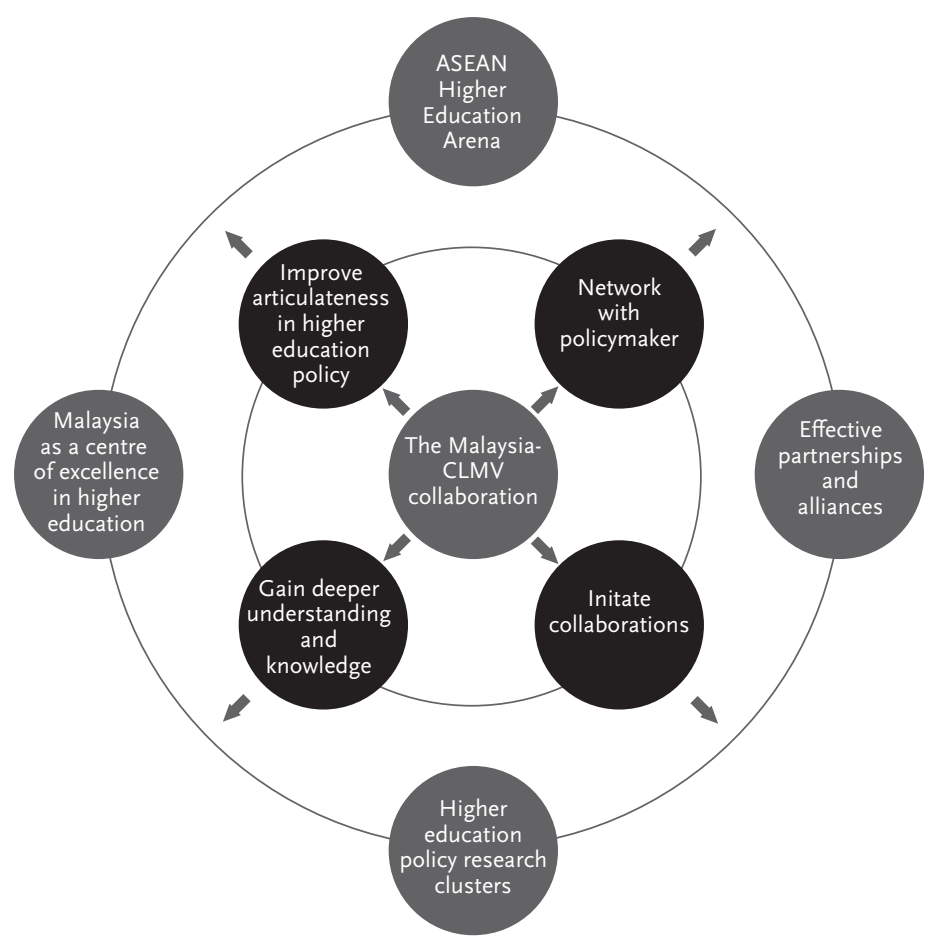

Source: Tan, Rozinah and Morshidi, 2012

The framework is further operationalised into two major dimensions: human capital development, and networking and system development. In terms of the first, the strategies include training, education and research and projects may include work attachment in Malaysia, a sponsored programme for CLMV students or cross-country research projects. The two strategies to promote networking and system development are research funding and infrastructure. They include providing a platform for Malaysian and CLMV researchers to collaborate for international research grants and providing access to technology, equipment and facilities for CLMV researchers in Malaysia. Based on seed grants from the Malaysian MOHE, research activities and projects in five clusters were carried out: research, teaching and learning, community engagement and student mobility, quality assurance, and leadership. 
To date, four phases of research-based projects have been commissioned that involve Malaysian academics in public and private HEIs collaborating and engaging with their counterparts in CLMV countries (see Izzahar, 20I7). These successful and impactful projects include social and economic integration in Cambodia in the area of energy education, a sustainable framework for an informational technology (IT) human and infrastructure resources development ecosystem, green development, improving women's sexual health, expanding opportunities for basic and tertiary education, and an oral health programme. A project was also launched to develop affordable technology to provide arsenic-safe potable water in rural areas of Cambodia. Apart from developmental cooperation through research and community engagement, capacity building was offered to university staff in Cambodia to develop their students' soft skills, and e-learning projects were established in Vietnamese schools as well as framework for teaching the English language based on the Malaysian University English Test, a pre-requisite for admittance to Malaysian HEIs. The Malaysian Qualifications Agency participated in this programme and engaged with HE policymakers in CLMV countries to assist them to develop basic principles for a national quality assurance system.

\section{Malaysian Technical Cooperation Programme}

The Malaysian Technical Cooperation Programme (MTCP) is a government-to-government form of South-South cooperation that was established in 1980. Through this programme, Malaysia shares its development experience and expertise with other developing countries. In addition, the MTCP aims to strengthen bilateral relations between Malaysia and other developing countries through promoting technical cooperation, strengthening regional cooperation and nurturing collective self-reliance. The programme is premised on the belief that quality of human resources is the key to a country's development. The key areas are public administration, good governance, health services, education, sustainable development, agriculture, poverty alleviation, investment promotion, information, communication and technology (ICT) and banking. Since 1980, more than I00 courses have been offered by various MTCP training institutions, benefitting more than 25,000 participants from 140 countries.

The MTCP is a broad programme that goes beyond HE. It includes short- and long-term courses, study visits and attachments, expert services, socio-economic development projects, and the supply of equipment and materials. In terms of HE, through the Ministry of Higher Education, the MTCP offers four scholarship programmes to international students to pursue academic studies in Malaysian institutions, namely: Malaysia 
International Scholarship, MTCP Scholarship for Postgraduate Studies, Commonwealth Scholarship and Fellowship Plan, and Islamic Development Bank Scholarship. Some Malaysian HEIs, both public and private, also offer short courses under the MTCP programme.

\section{Southeast Asian Ministers of Education Organization}

Malaysia is also indirectly involved in South-South cooperation though the Southeast Asian Ministers of Education Organization (SEAMEO). This regional inter-governmental organisation was established in I965 to promote regional cooperation in education, science and culture. Malaysia is one of II member countries and contributes actively to this form of South-South cooperation. In addition to member countries in the region, SEAMEO has eight associate member countries, among them developed ones.

SEAMEO has 2I specialist institutes across the region, of which Malaysia hosts three, the SEAMEO Regional Centre for Education in Science and Mathematics in Penang, the SEAMEO TROPMED Regional Centre for Microbiology, Parasitology and Entomology and the SEAMEO Regional Centre for Special Education in Kuala Lumpur.

\section{Commonwealth Tertiary Education Facility}

The Commonwealth Tertiary Education Facility (CTEF) is a collaborative effort between Malaysia's Ministry of Higher Education and the Commonwealth Secretariat in London that aims to strengthen the links between Commonwealth countries in developing tertiary education. As the majority of the countries in the Commonwealth are developing, the key role of the CTEF is to provide policy advice and guidance to the ministers responsible for tertiary or higher education. The CTEF also aims to become the referral centre for the Commonwealth and other international agencies to share good practices, expertise and research collaboration towards sustainable tertiary education.

Established in 20I3, the CTEF has to date embarked on two major projects leading to the preparation of Issues Papers for the Conference of Commonwealth Education Ministers. The first project focuses on policy options in financing HE for the Commonwealth Pacific and the second examines doctoral education in Commonwealth Africa. Both collect reliable and up-to-date information as well as good practices with respect to financing and doctoral education, and disseminate this to member countries to assist them in developing their own policies.

The CTEF is an example of South-South collaboration where Malaysia as the more developed South provides seed money and logistical support by housing the Facility at the National Higher Education Research Institute 
at Universiti Sains Malaysia, and through the CTEF, reaching out to other developing countries within the Commonwealth.

\section{Africa-Asia Development University Network (see note)}

The Africa-Asia Development University Network (AADUN) is a network of universities, libraries, research institutions and centres of excellence that aims to promote research that leads to sustainable development in Asia and Africa. It was established following an Asia-Africa conference in 2005 and is an intellectual platform to enhance collaboration between academic institutions and research centres on the two continents, as well as to identify good practices in research and development in seven target areas: sustainable water management, renewable energy, ecosystems, women in science and technology development, food security, public health and disability studies. Initially funded by the Government of Japan and established in collaboration with UNOSSC in 2008 , the network secretariat is now based at the University of Malaya in Malaysia.

AADUN operates on several fronts, one of which is developing working relationships with African students at the University of Malaya. This includes joint supervision of doctoral dissertations and helping African students to collaborate with African experts while pursuing their academic programme in Asia. The AADUN also publishes the African Studies Working Paper Series and AADUN Policy Briefs to highlight the initial research findings of projects undertaken by this network. These working papers and policy briefs are occasionally presented at workshops in order to disseminate the findings and obtain feedback from stakeholders. The AADUN scouts for potential academic journals to turn these working papers into journal articles.

To date, the AADUN has coordinated research projects in four broad areas:

- African history: Arts and culture, civilisation, language

- Ethnicity, Identity, Politics, Religion and Conflict

- Sustainable development, Politics and Governance: Africa and Asia

- Inter-regional engagement: Africa and Asia

It has also organised several international conferences in collaboration with the Centre for Chinese Studies at Stellenbosch University and on "Africa's Asian Options" at a research centre based at Goethe University in Frankfurt, Germany. African and Asian scholars hold annual roundtable discussions on issues such as Engaging Africa, African-Asian Encounters, and Afrasian Transformations from a broad range of interdisciplinary perspectives such as politics and governance, conflict studies, intercultural studies, business studies, science and technology, food security, rural development and other related work in humanities. 


\section{Conclusion}

Malaysia has always been committed to South-South cooperation and collaboration, starting with the establishment of the MTCP in I980 and active involvement and contribution in SEAMEO and other regional groupings. Such cooperation has permeated many spheres of international engagement, such as geopolitics, economics, education and culture. South-South cooperation has also been extended to HE, with efforts to internationalise Malaysian HE. Many programmes and projects have been initiated at regional, national and institutional levels. These have different objectives and outcomes. For instance MGR aims to develop soft power influence and understand other developing countries around Malaysia, the CLMV programme is intended for capacity building and developing collaborative opportunities, and the MTCP programme offers technical assistance and capacity building. However, the overarching goal of all these initiatives is to enhance South-South interaction and cooperation between Malaysia and developing countries. Looking ahead, the country aims to steer the ASEAN Community towards bringing other developing and least developing nations within ASEAN into the mainstream of development in Southeast Asia. If successful, this will showcase and reiterate Malaysia's efforts and commitment to South-South cooperation.

Note: The authors acknowledge the written contribution from AADUN by Dr Ray Ikechukwu Jacob and Professor Azirah Hashim (personal communication, January 2I, 20I6).

\section{References}

Alatas, S. F. (2006). Alternative Discourses in Asian Social Science: Responses to Eurocentrism. New Delhi: Sage.

Amanor,K. S. (20I3). South-south cooperation in Africa: Historical, geopolitical and political economy dimensions of international development. IDS Bulletin 44 (4), 20-30.

Chakrabarty, D. (2000). Provincializing Europe: Postcolonial thought and historical difference. Princeton: Princeton University Press.

Connell, R. (20I4). Using southern theory: Decolonizing social thought in theory, research and application. Planning Theory I3 (2), 210-223.

Izzahar, R. (20I7). Building bridges and investing in people: The success of strategic partnerships and alliances between Malaysia and CLMV countries. Penang: National Higher Education Research Institute.

Maxwell, S. (1998). Comparisons, convergence and connections: Development studies in north and south. IDS Bulletin 29 (I), 20-3I.

Ministry of Education (MOE) (20I4). National Education Statistic: Higher education sector. Putrajaya: Ministry of Education Malaysia. 
Ministry of Education (MOE) (20I5a). Malaysia Education Blueprint (Higher Education) 2015-2025. Putrajaya: Ministry of Education Malaysia.

Ministry of Education (MOE) (20I5b). Malaysia's Global Reach: Touching lives and transforming futures. Putrajaya: Ministry of Education Malaysia.

Ministry of Higher Education (MOHE) (2007). National Higher Education Strategic Plan Beyond 2020.Putrajaya: Ministry of Higher Education Malaysia.

Ministry of Higher Education (MOHE) (2OII). NHESP 2 Malaysia's Global Reach: A new dimension. Putrajaya: Ministry of Higher Education Malaysia.

Tan, C., Rozinah, J. and Morshidi, S. (20I2). The Malaysia-CLMV Collaboration. In Rozinah, J., M. L. Y. A., Ng, andSarjit, K. (Eds.) Higher Education and Human Capital Development between Malaysia and CLMV: Towards strategic partnerships and alliances. Penang: National Higher Education Research Institute, I-6.

United Nations Office for South-South Cooperation (UNOSSC) (no date). What is south-south cooperation? Accessed January 2I, 2016 at http:// ssc.undp.org/content/ssc/about/what_is_ssc.html 